\title{
Aqueous Suzuki Coupling Reactions of Basic Nitrogen- Containing Substrates in the Absence of Added Base and Ligand: Observation of High Yields under Acidic Conditions
}

Zhao $\mathrm{Li}^{\dagger}$, Carol Gelbaum ${ }^{\dagger}$, Jason S. Fisk ${ }^{\S}$, Bruce Holden ${ }^{\S}$, Arvind Jaganathan ${ }^{\S}$, Gregory T. Whiteker $^{\mathfrak{t}}$, Pamela Pollet ${ }^{\dagger}$, and Charles L. Liotta* ${ }^{\dagger \dagger}$

${ }^{\dagger}$ School of Chemistry and Biochemistry, Georgia Institute of Technology, Atlanta, Georgia 30332, USA

"School of Chemical and Biomolecular Engineering, Georgia Institute of Technology, Atlanta, Georgia 30332, USA

${ }^{\S}$ The Dow Chemical Company, Midland, Michigan 48674, USA

${ }^{£}$ Dow AgroSciences, Indianapolis, Indiana 46268, USA

\section{Contents}

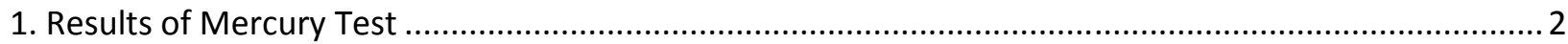

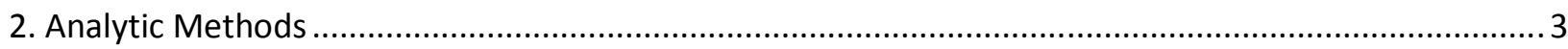

2.1. Comparison of Reaction Yields Determined by Various Analytic Methods ..................................... 3

2.2. GC-FID Chromatograms and Calibration Curves ........................................................................... 3

2.3. Examples of ${ }^{1} \mathrm{H}$ NMR Spectra for Crude Products............................................................................. 7

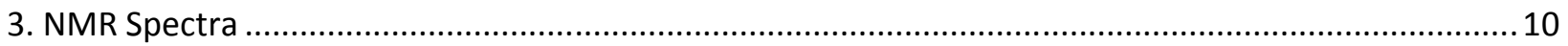




\section{Results of Mercury Test}

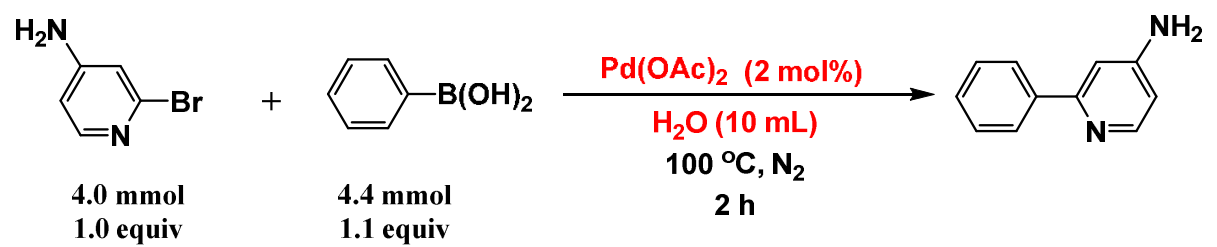

\begin{tabular}{|c|c|c|c|}
\hline $\begin{array}{c}\text { Hg (equiv) } \\
\text { relative to Pd }\end{array}$ & $\begin{array}{c}\text { GC Yield } \\
\text { (\%) }\end{array}$ & Initial $\mathbf{~ p H}$ & Final $\mathbf{~ H ~}$ \\
\hline $\mathbf{0}$ & 100 & 6.5 & 2.3 \\
\hline $\mathbf{2 0}$ & 98.1 & 6.3 & 3.6 \\
\hline $\mathbf{5 0}$ & 72.6 & 6.6 & 5.1 \\
\hline $\mathbf{1 5 0}$ & 38.5 & 6.5 & 5.0 \\
\hline $\mathbf{3 0 0}$ & 40.6 & 6.3 & 5.0 \\
\hline
\end{tabular}

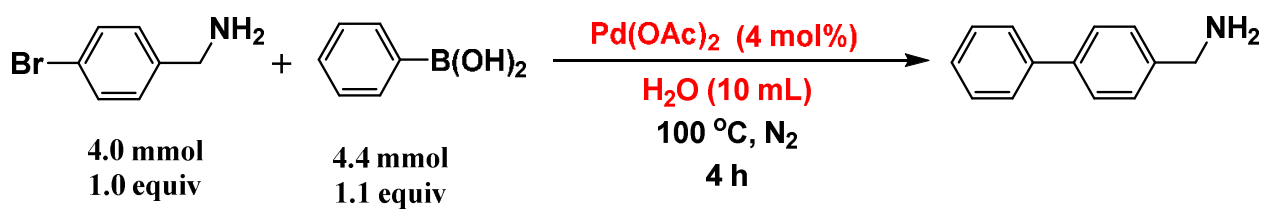

\begin{tabular}{|c|c|c|c|}
\hline $\begin{array}{c}\text { Hg (equiv) } \\
\text { relative to } \mathbf{P d}\end{array}$ & $\begin{array}{c}\text { GC Yield } \\
\text { (\%) }\end{array}$ & Initial $\mathbf{~ H ~}$ & Final $\mathbf{~ H H}$ \\
\hline $\mathbf{0}$ & 88.8 & 8.6 & 2.1 \\
\hline $\mathbf{1 0}$ & 63.1 & 8.9 & 5.7 \\
\hline $\mathbf{2 5}$ & 44.7 & - & - \\
\hline $\mathbf{1 5 0}$ & 25.1 & 8.7 & 6.7 \\
\hline
\end{tabular}




\section{Analytic Methods}

\subsection{Comparison of Reaction Yields Determined by Various Analytic Methods}

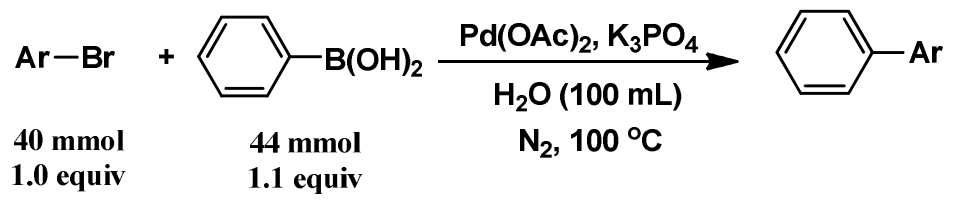

The isolated yields for two model reactions are consistent with the yields determined by $\mathrm{GC}$ and ${ }^{1} \mathrm{H}$ NMR. As a consequence, GC and/or ${ }^{1} \mathrm{H}$ NMR were employed for in-situ determination of the yields for the coupling reactions for a wide variety of aryl substrates in this work.

\begin{tabular}{|c|c|c|c|c|c|c|}
\hline Aryl Bromide & Product & $\begin{array}{c}\text { Pd(OAc) } \\
\text { (equiv) }\end{array}$ & $\begin{array}{c}\mathrm{K}_{3} \mathrm{PO}_{4} \\
\text { (equiv) }\end{array}$ & $\begin{array}{c}\text { Time } \\
\text { (h) }\end{array}$ & \multicolumn{3}{|c|}{ Yield (\%) } \\
\hline Isolated* & GC-FID & ${ }^{1} \mathrm{H}$ NMR \\
\hline
\end{tabular}

\subsection{GC-FID Chromatograms and Calibration Curves}

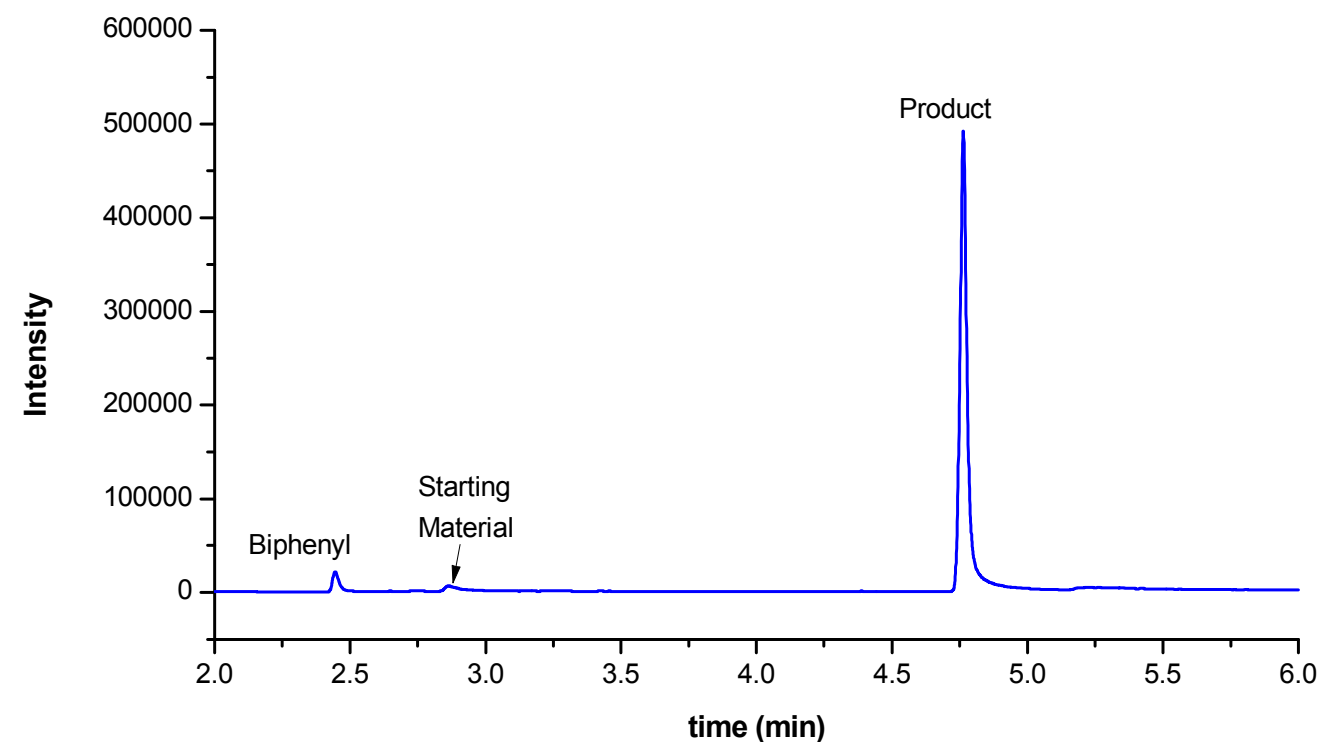

Figure S1. GC-FID chromatogram of the $\mathrm{Pd}(\mathrm{OAc})_{2}(0.2 \mathrm{mmol})$ catalyzed reaction between 4amino-2-bromopyridine $(10 \mathrm{mmol})$ and $\mathrm{PhB}(\mathrm{OH})_{2}(11 \mathrm{mmol})$ in water $(25 \mathrm{~mL})$ without added base in $\mathrm{N}_{2}$ at $100{ }^{\circ} \mathrm{C}$ for $2 \mathrm{~h}$, after workup. 


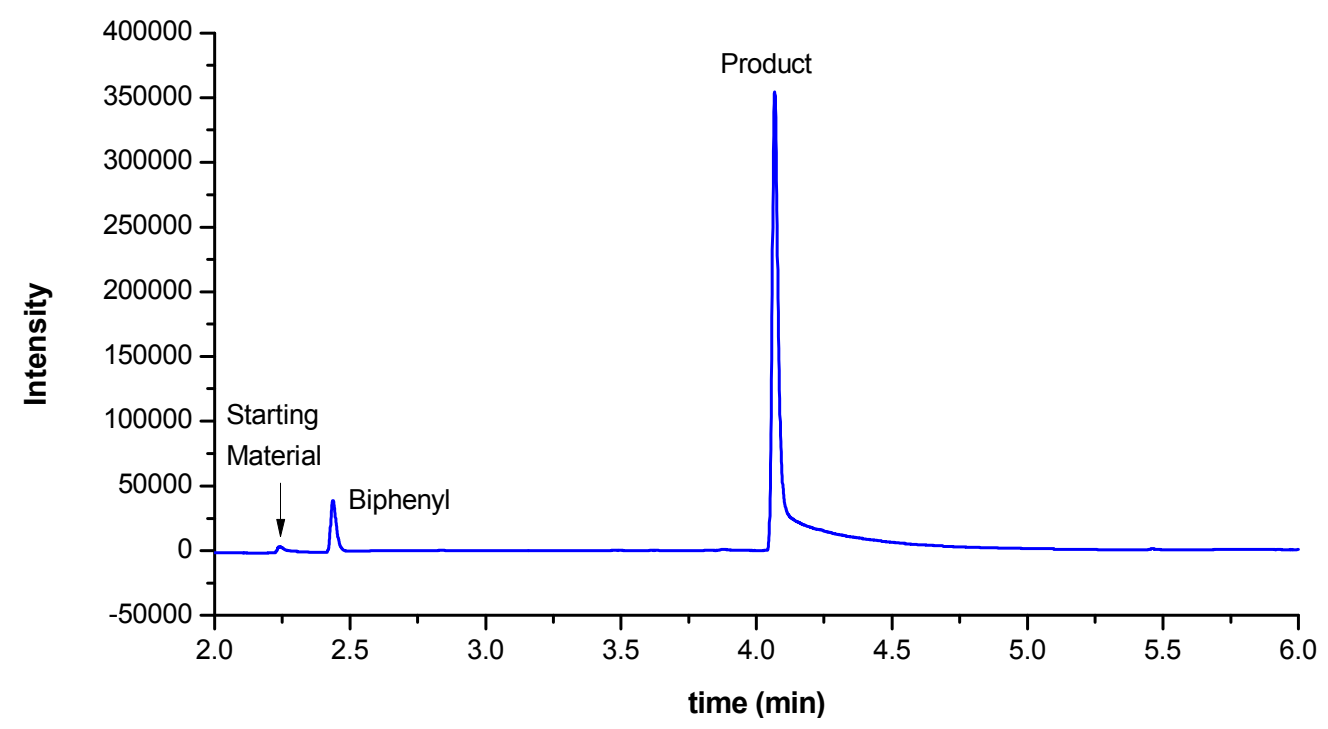

Figure S2. GC-FID chromatogram of the $\mathrm{Pd}(\mathrm{OAc})_{2}(0.4 \mathrm{mmol})$ catalyzed reaction between 4bromobenzylamine $(10 \mathrm{mmol})$ and $\mathrm{PhB}(\mathrm{OH})_{2}(11 \mathrm{mmol})$ in water $(25 \mathrm{~mL})$ without added base in $\mathrm{N}_{2}$ at $100^{\circ} \mathrm{C}$ for $4 \mathrm{~h}$, after workup.

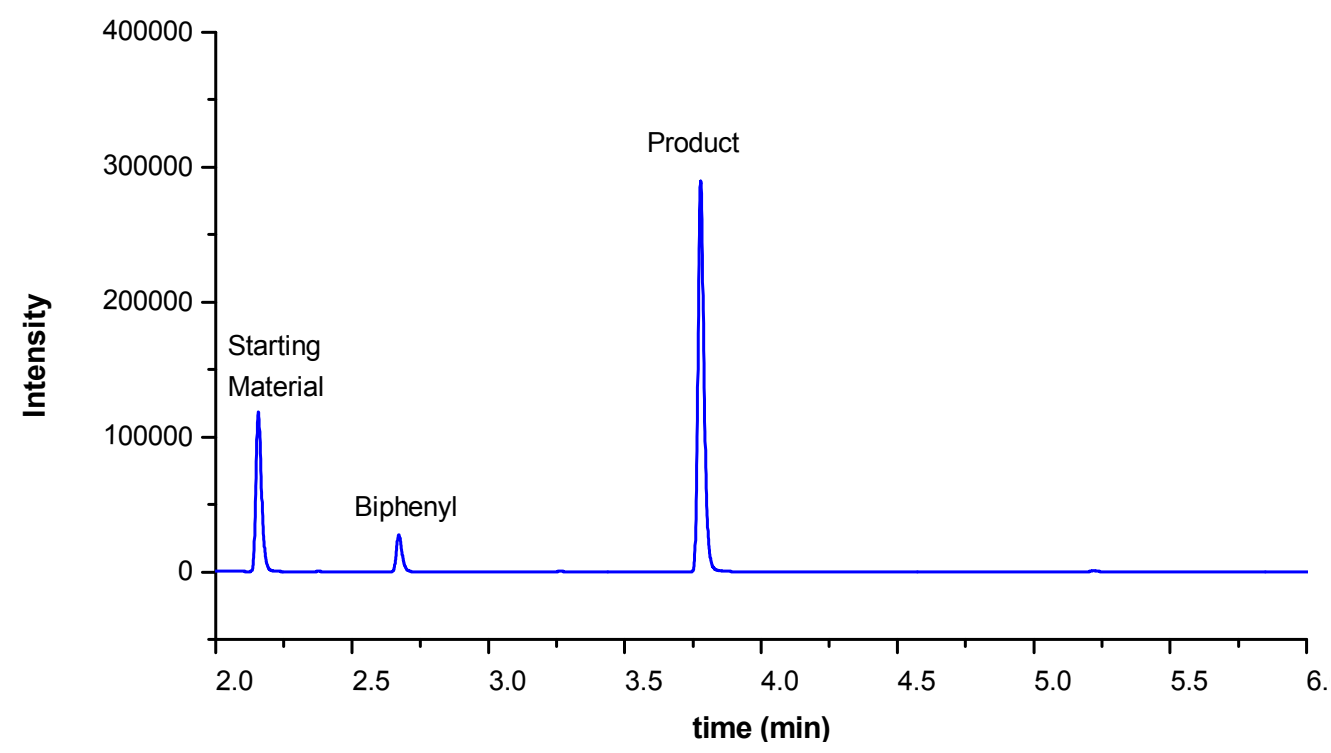

Figure S3. GC-FID chromatogram of the $\mathrm{Pd}(\mathrm{OAc})_{2}(2 \mathrm{mmol})$ catalyzed reaction between 4bromoanisole $(40 \mathrm{mmol}), \mathrm{PhB}(\mathrm{OH})_{2}(44 \mathrm{mmol}), \mathrm{K}_{3} \mathrm{PO}_{4}(40 \mathrm{mmol})$ in water $(100 \mathrm{~mL})$ in $\mathrm{N}_{2}$ at 100 ${ }^{\circ} \mathrm{C}$ for $4 \mathrm{~h}$, after workup.

Calibration curves were created from pure substrate and product standards (commercial or synthesized). Stock solutions $(0.1 \mathrm{M}, 5$ or $10 \mathrm{~mL}$ ) were made using methanol as solvent. Multiple samples of concentrations between $0.005 \mathrm{M}$ and $0.05 \mathrm{M}$ were then made 
from dilution of the stock solution with methanol and analyzed by GC-FID fitted with a capillary column ( $30 \mathrm{~m} \times 0.32 \mathrm{~mm} \times 1.00 \mu \mathrm{m}$, length $\times$ inside diameter $\times$ film thickness). Plots of concentration versus area were created for each compound using Microsoft Excel and a trendline analysis used to provide the calibration curve and confirm that the plot followed a straight line. This procedure was exemplified by the calibration curve for 4-bromobenzylamine shown in the table below.

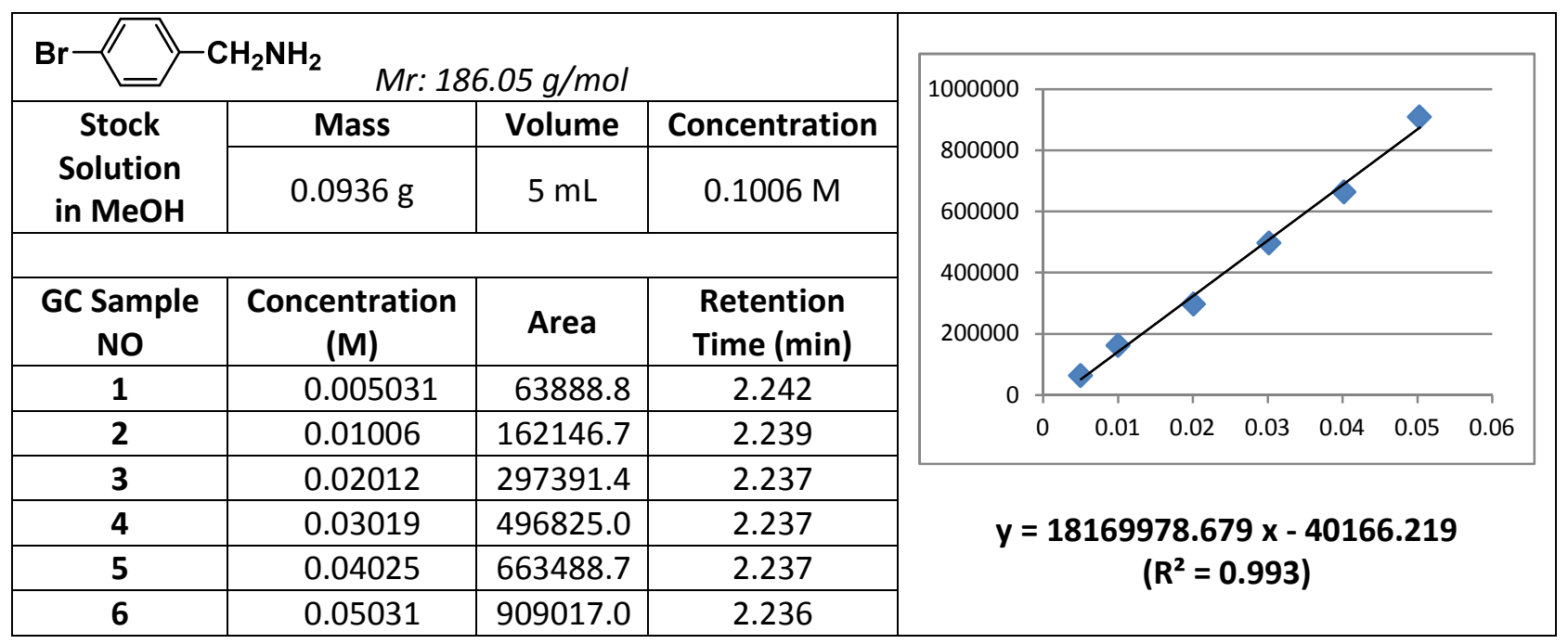

\section{List of Calibration Curves}

\begin{tabular}{|c|c|c|c|c|}
\hline \multirow{2}{*}{$\begin{array}{c}\text { Substrates } \\
\text { S= Commercial } \\
\text { S= Synthesized }\end{array}$} & Slope & Intercept & $R^{2}$ \\
\cline { 3 - 6 } & $\mathrm{C}$ & 12547136.432 & 0 & 0.999 \\
\hline
\end{tabular}




\begin{tabular}{|c|c|c|c|c|}
\hline \multirow{2}{*}{$\begin{array}{c}\text { Substrates } \\
\qquad \mathrm{Ar}-\mathrm{Br}\end{array}$} & \multirow{2}{*}{$\begin{array}{c}\text { Source } \\
C=\text { Commercial } \\
S=\text { Synthesized }\end{array}$} & \multicolumn{3}{|c|}{ Calibration Curve } \\
\hline & & Slope & Intercept & $\mathbf{R}^{2}$ \\
\hline & $S$ & 23496483.640 & -33206.284 & 0.999 \\
\hline & $\mathrm{S}$ & 32292410.277 & -54988.486 & 0.999 \\
\hline & $S$ & 37846827.485 & -50367.608 & 1.000 \\
\hline & $\mathrm{S}$ & 33972419.737 & -65782.087 & 0.997 \\
\hline & C & 10368344.436 & -11334.078 & 0.999 \\
\hline & C & 10543693.686 & -12130.136 & 1.000 \\
\hline & C & 12398707.527 & -23492.968 & 0.999 \\
\hline & C & 9902853.230 & 0 & 1.000 \\
\hline & C & 12025779.559 & -24524.976 & 0.999 \\
\hline & C & 12690919.599 & -10902.424 & 0.999 \\
\hline & C & 10994830.651 & -8710.411 & 1.000 \\
\hline & C & 13939331.948 & 0 & 0.999 \\
\hline & C & 12368244.282 & -17543.399 & 1.000 \\
\hline & C & 13738077.730 & -29482.410 & 0.997 \\
\hline & C & 13939331.948 & 0 & 0.999 \\
\hline
\end{tabular}

\begin{tabular}{|c|c|c|c|c|}
\hline \multirow{2}{*}{ Products } & \multirow{2}{*}{$\begin{array}{c}\text { Source } \\
\text { C=Commercial } \\
\text { S= Synthesized }\end{array}$} & Slope & Intercept & $\mathbf{R}^{\mathbf{2}}$ \\
\cline { 3 - 5 } & $\mathrm{C}$ & 34556455.924 & 0 & 0.999 \\
\hline
\end{tabular}




\begin{tabular}{|c|c|c|c|c|}
\hline & $\mathrm{C}$ & 29588530.766 & -51355.658 & 0.998 \\
\hline
\end{tabular}

\subsection{Examples of ${ }^{1} \mathrm{H}$ NMR Spectra for Crude Products}

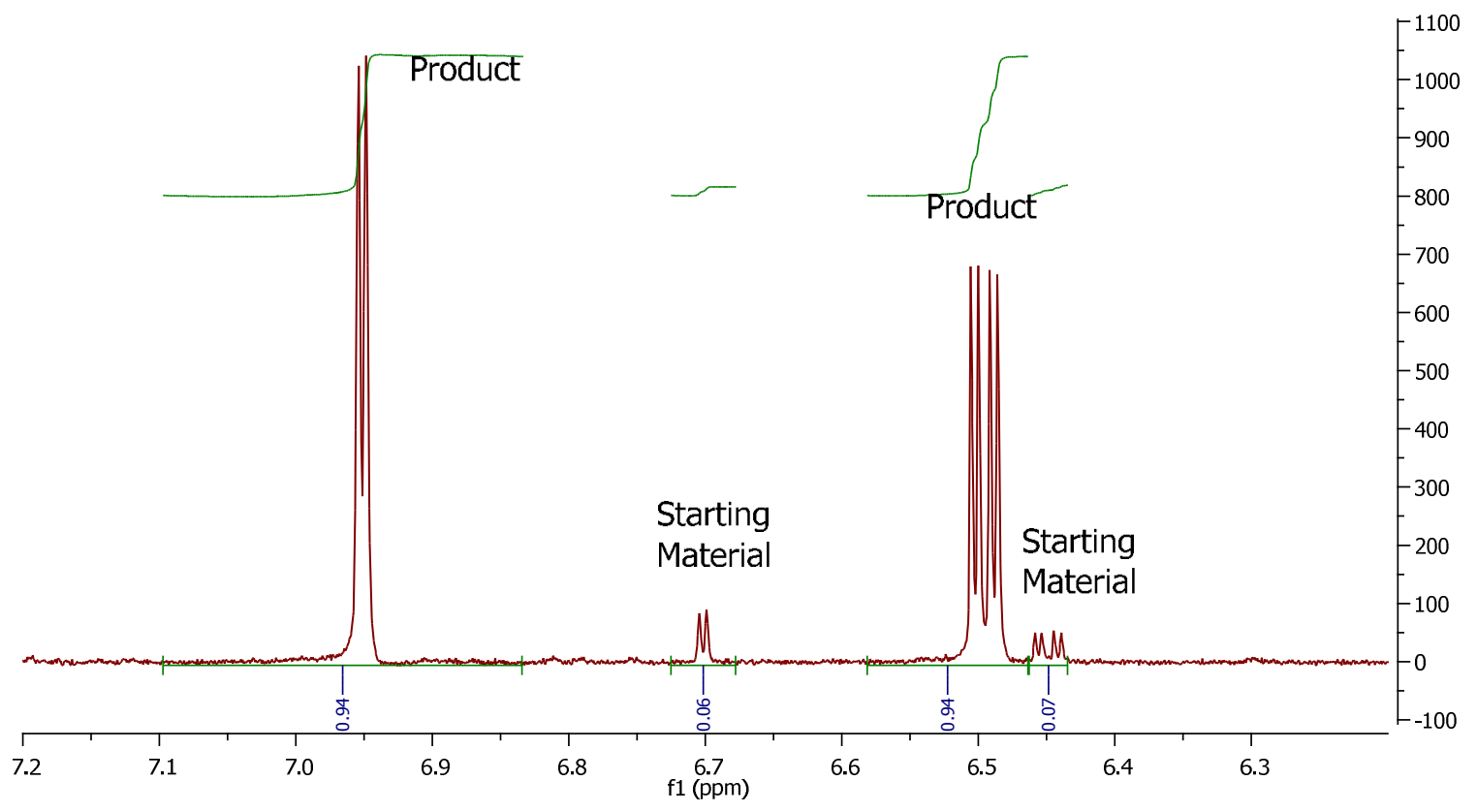

Figure S4. ${ }^{1} \mathrm{H} N M R\left(400 \mathrm{MHz}\right.$ in $\left.\mathrm{CDCl}_{3}\right)$ of the $\mathrm{Pd}(\mathrm{OAc})_{2}(0.2 \mathrm{mmol})$ catalyzed reaction between 4-amino-2-bromopyridine $(10 \mathrm{mmol})$ and phenylboronic acid $(11 \mathrm{mmol})$ in water $(25 \mathrm{~mL})$ without added base in $\mathrm{N}_{2}$ at $100{ }^{\circ} \mathrm{C}$ for $2 \mathrm{~h}$, after workup. 


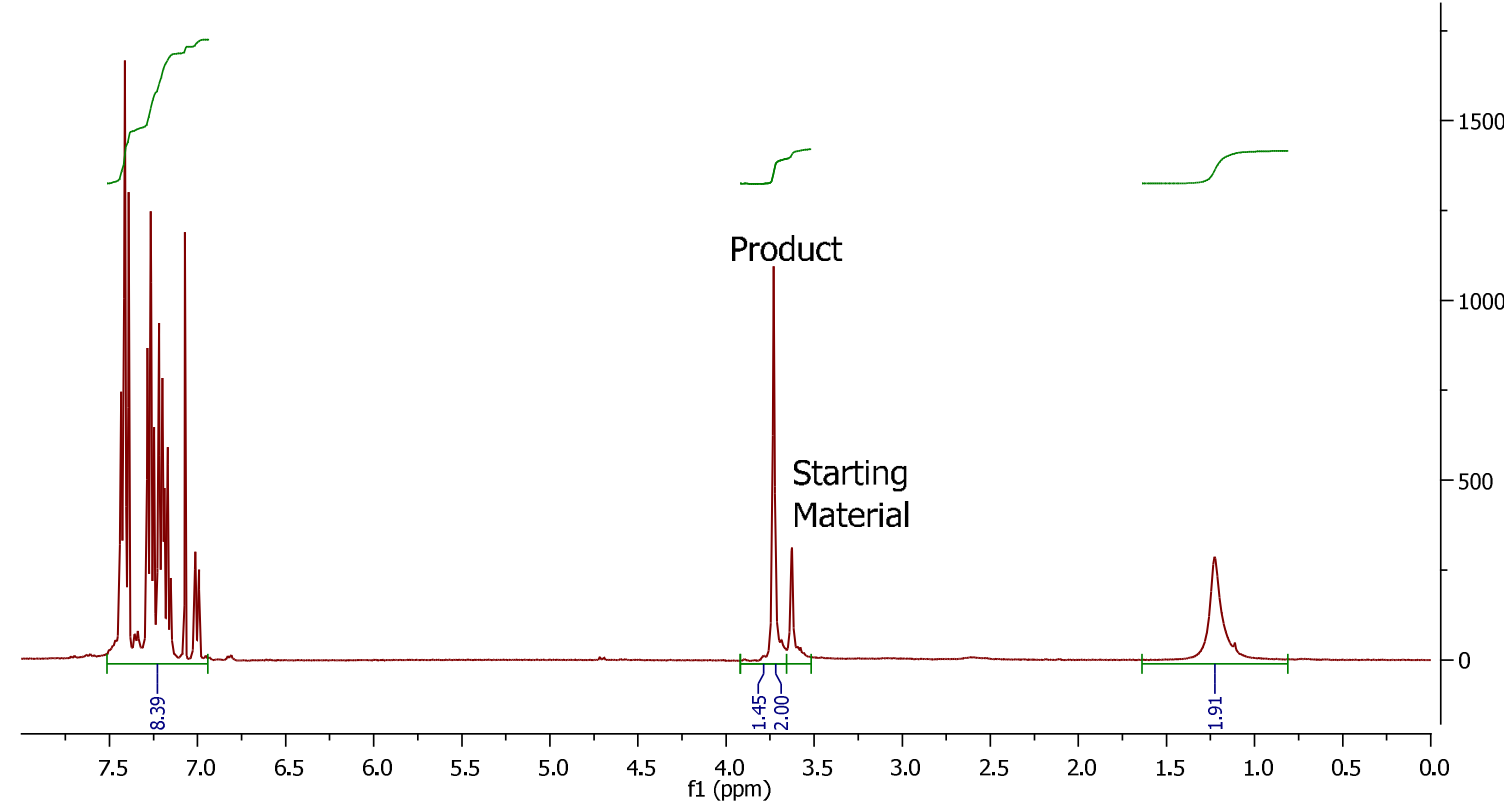

Figure S5. ${ }^{1} \mathrm{H} \mathrm{NMR}\left(400 \mathrm{MHz}\right.$ in $\left.\mathrm{CDCl}_{3}\right)$ of the $\mathrm{Pd}(\mathrm{OAC})_{2}(0.2 \mathrm{mmol})$ catalyzed reaction between 4-bromobenzyl amine $(10 \mathrm{mmol})$ and phenylboronic acid $(11 \mathrm{mmol})$ in water $(25 \mathrm{~mL})$ without added base in $\mathrm{N}_{2}$ at $100{ }^{\circ} \mathrm{C}$ for $4 \mathrm{~h}$, after workup.

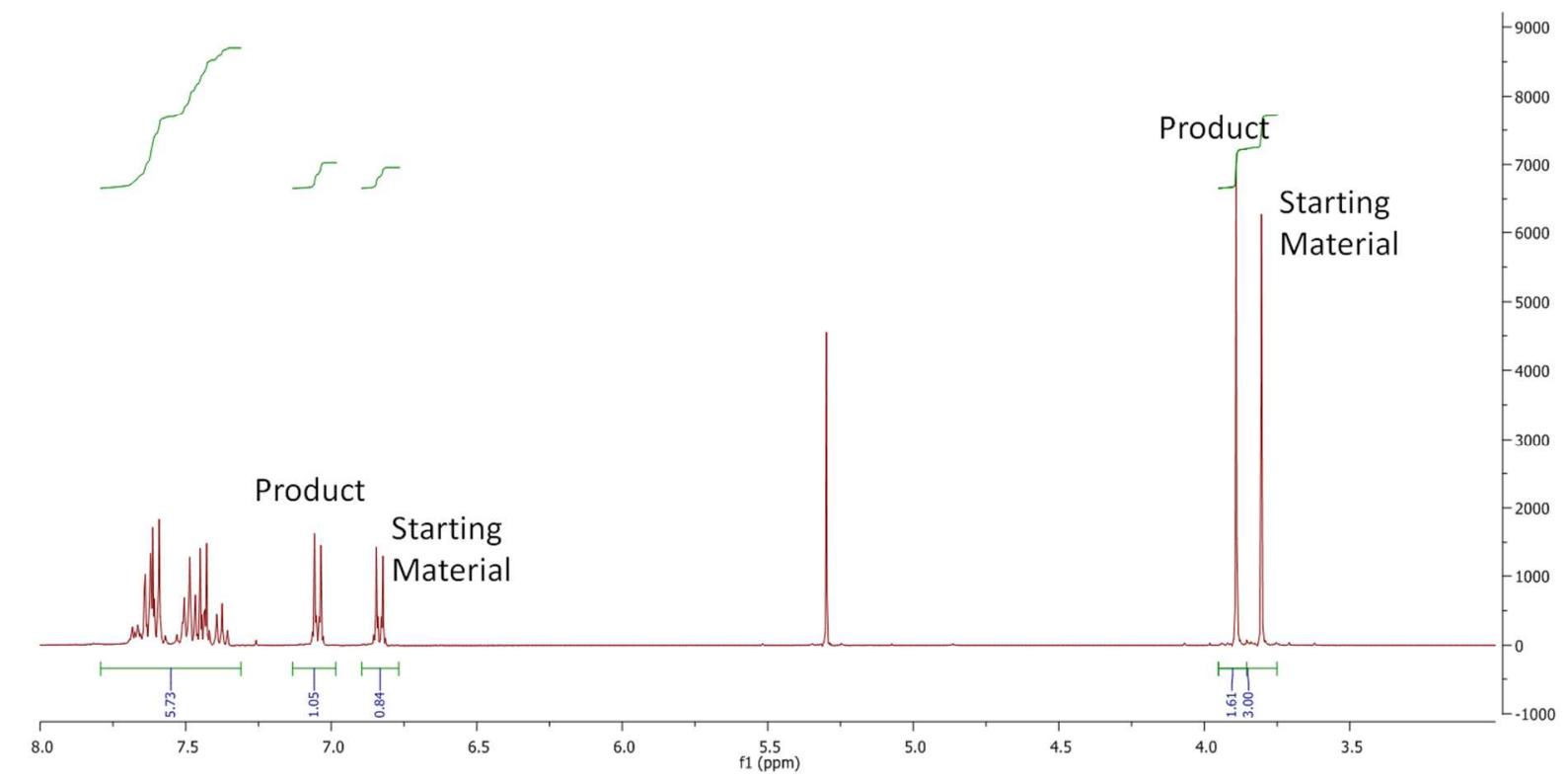

Figure S6. ${ }^{1} \mathrm{H} \mathrm{NMR}\left(400 \mathrm{MHz}\right.$ in $\left.\mathrm{CDCl}_{3}\right)$ of the $\mathrm{Pd}(\mathrm{OAC})_{2}(2 \mathrm{mmol})$ catalyzed reaction between 4bromoanisole $(40 \mathrm{mmol}), \mathrm{PhB}(\mathrm{OH})_{2}(44 \mathrm{mmol}), \mathrm{K}_{3} \mathrm{PO}_{4}(40 \mathrm{mmol})$ in water $(100 \mathrm{~mL})$ in $\mathrm{N}_{2}$ at 100 ${ }^{\circ} \mathrm{C}$ for $4 \mathrm{~h}$, after workup. 
NMR spectra were used to determine amount of starting material and product in reaction mixtures after workup by comparison to standards of each compound. NMR Yields were calculated according to the following:

$$
\text { Yield }_{N M R}=\frac{I_{\text {prod }}}{I_{S M}+I_{\text {prod }}}
$$

Where $I_{\text {prod. }}$ and $I_{S M}$ denote the area integrals of the product and substrate respectively. The chemical shifts for each product and starting material were confirmed via prepared standards and are consistent to reports in the literature. 


\section{NMR Spectra}

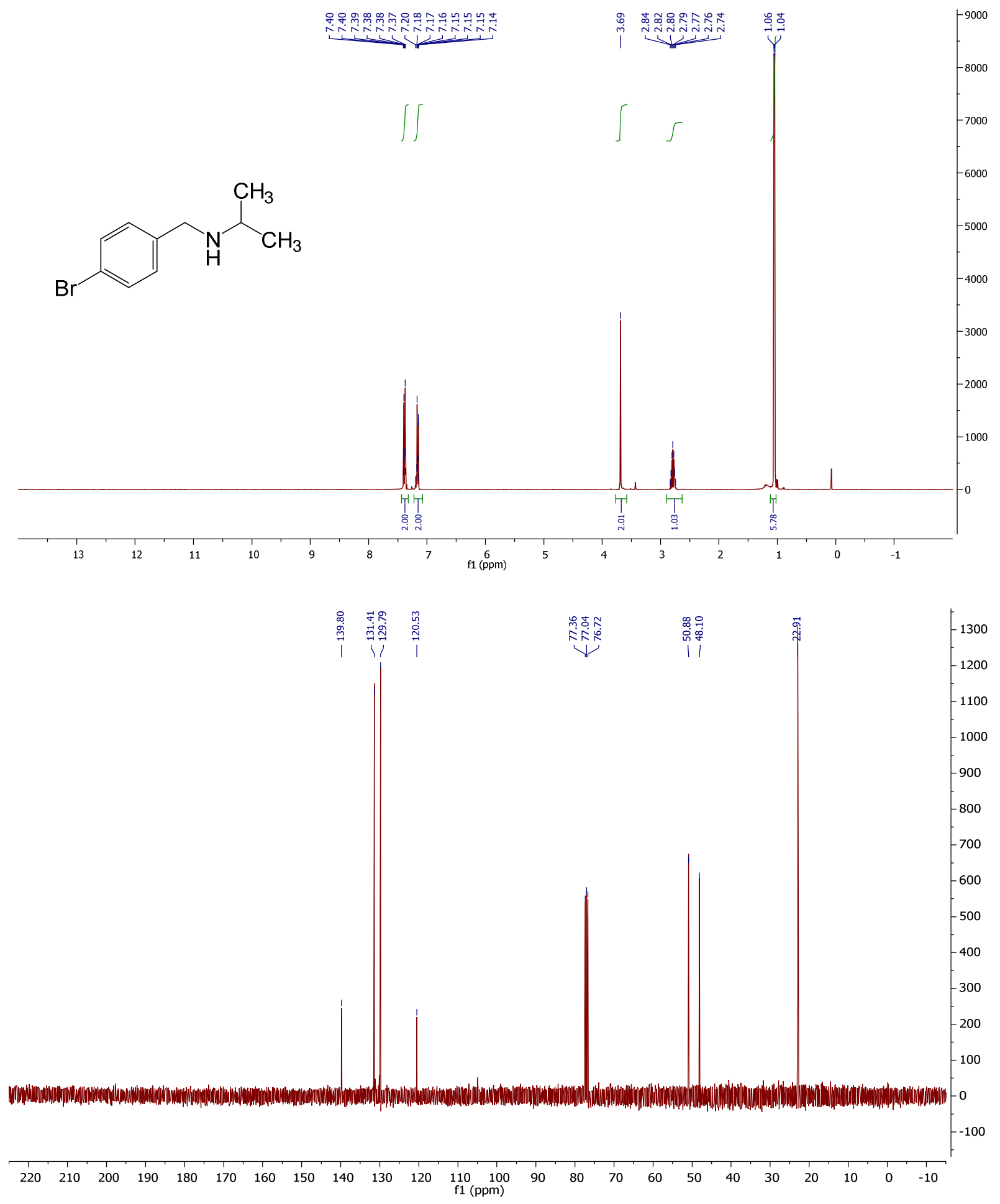

Figure S7. ${ }^{1} \mathrm{H}$ NMR (400 MHz) and ${ }^{13} \mathrm{C}$ NMR (100 MHz) spectra of 4-bromo- $N$ isopropylbenzylamine in $\mathrm{CDCl}_{3}$ 


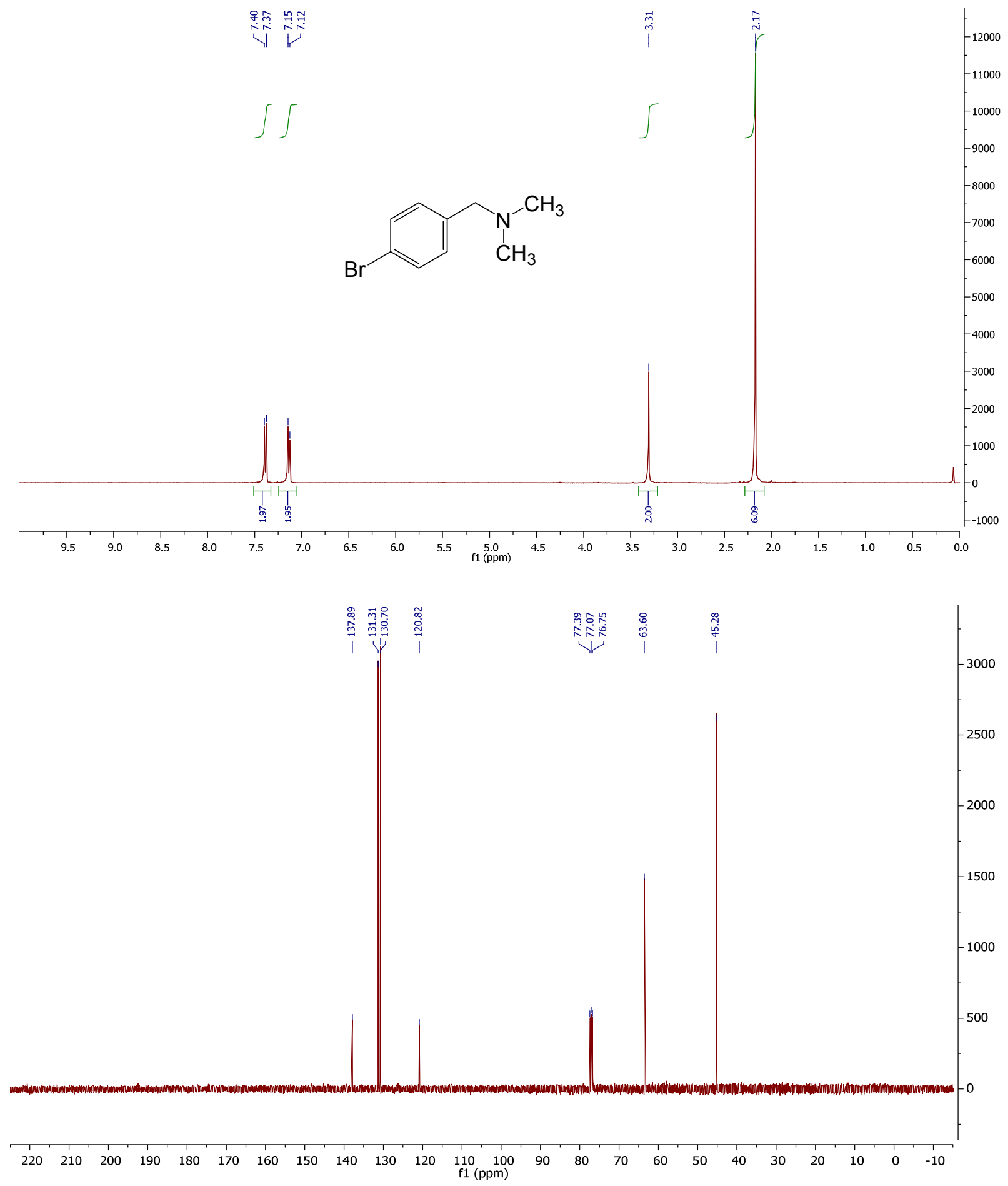

Figure S8. ${ }^{1} \mathrm{H}$ NMR (400 MHz) and ${ }^{13} \mathrm{C}$ NMR (100 MHz) spectra of 4-bromo- $N, N$ dimethylbenzylamine in $\mathrm{CDCl}_{3}$ 


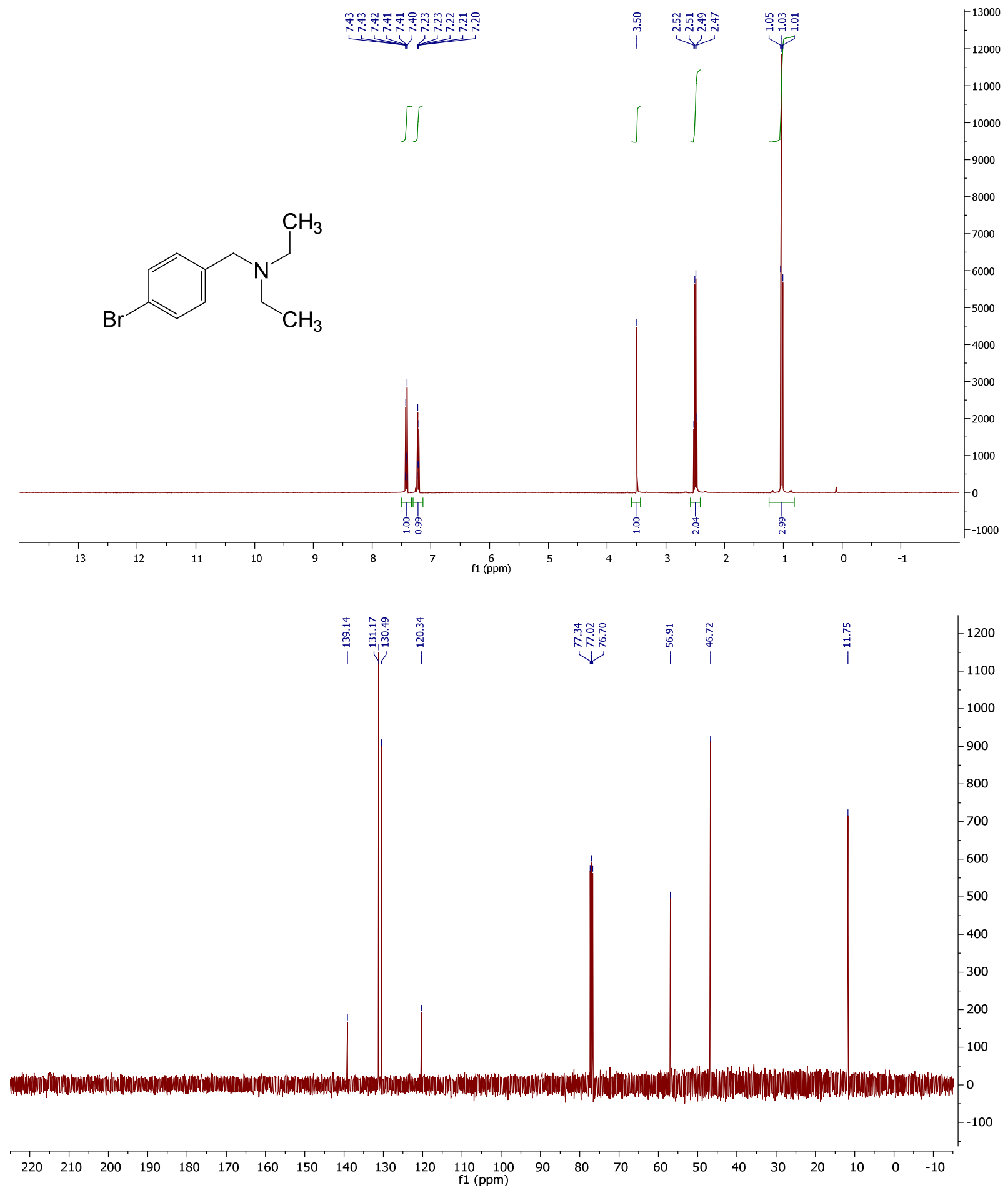

Figure 59. ${ }^{1} \mathrm{H}$ NMR (400 MHz) and ${ }^{13} \mathrm{C}$ NMR (100 MHz) spectra of 4-bromo- $N, N$ diethylbenzylamine in $\mathrm{CDCl}_{3}$ 


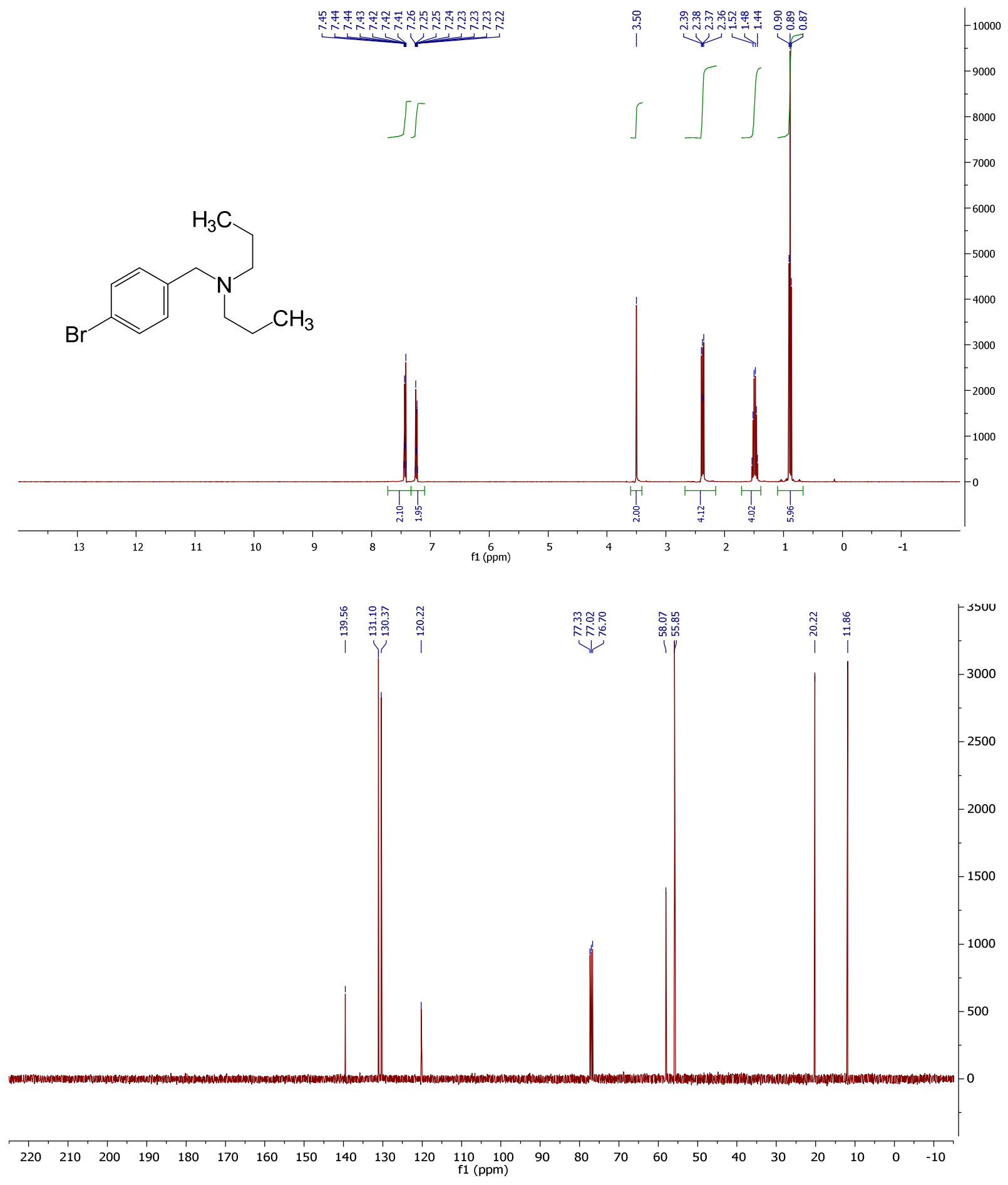

Figure S10. ${ }^{1} \mathrm{H}$ NMR (400 MHz) and ${ }^{13} \mathrm{C}$ NMR (100 MHz) spectra of 4-bromo- $N, N$ dipropylbenzylamine in $\mathrm{CDCl}_{3}$ 


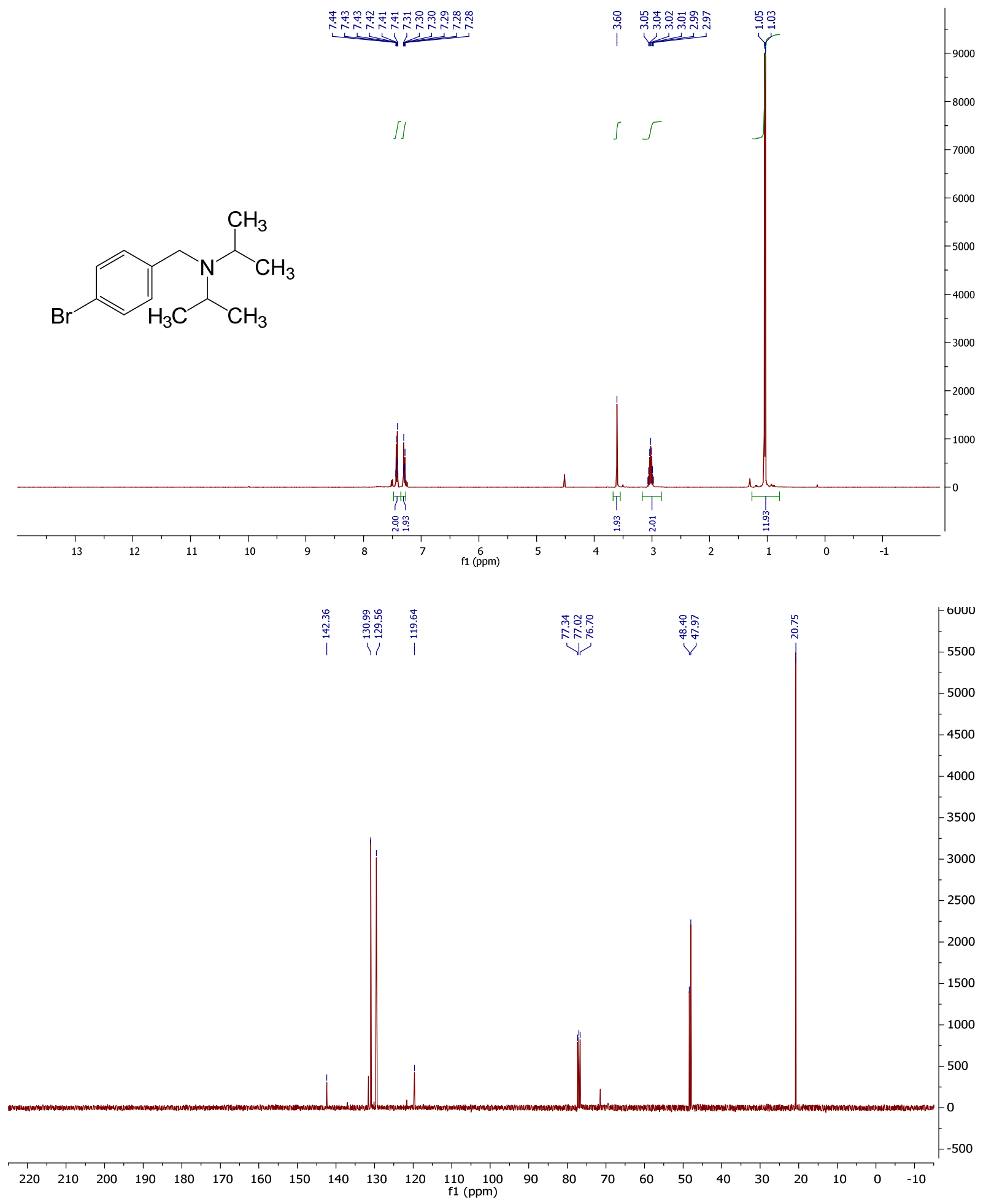

Figure S11. ${ }^{1} \mathrm{H}$ NMR (400 MHz) and ${ }^{13} \mathrm{C}$ NMR (100 MHz) spectra of 4-bromo- $N, N$ diisopropylbenzylamine in $\mathrm{CDCl}_{3}$ 


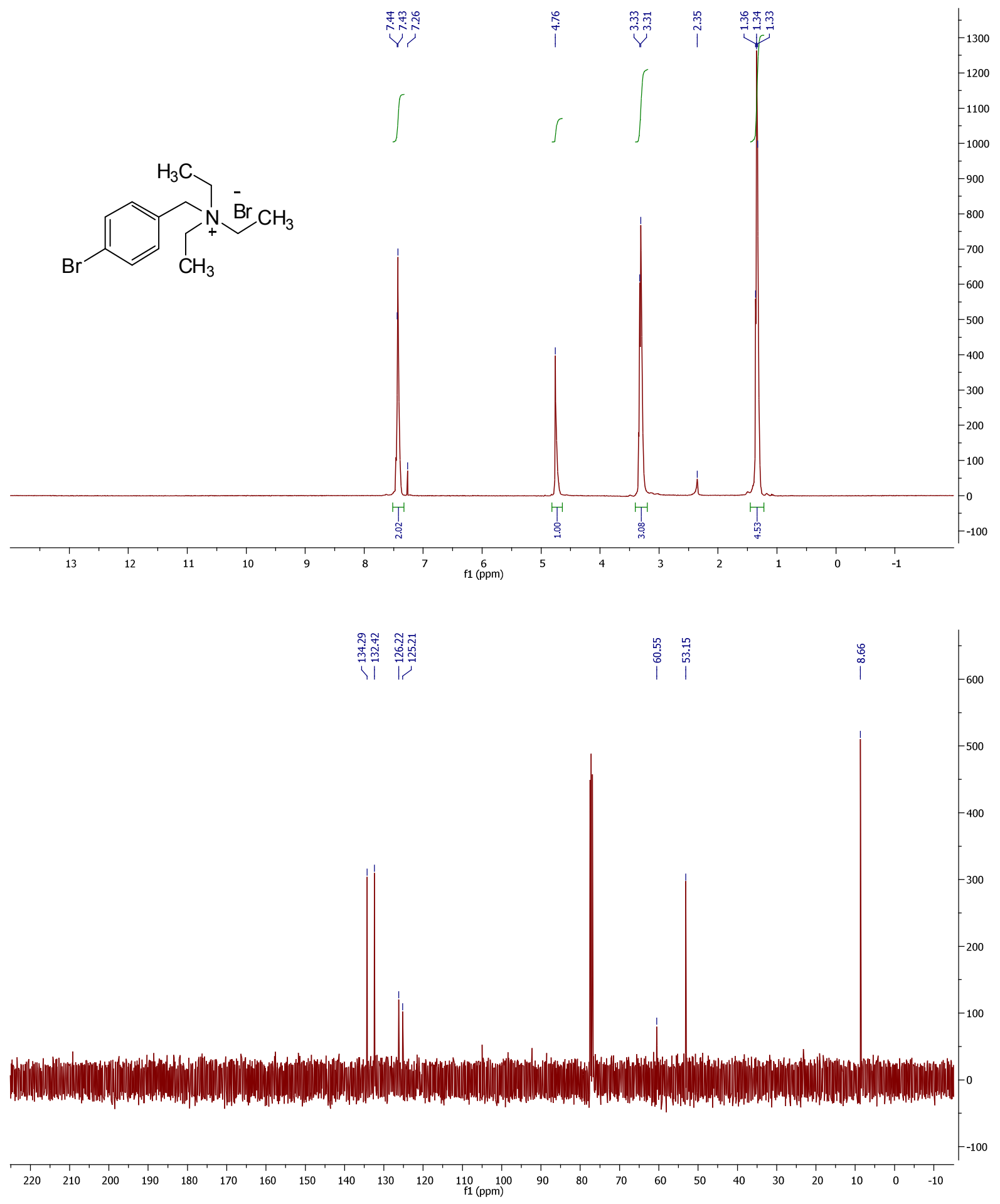

Figure S12. ${ }^{1} \mathrm{H}$ NMR (400 MHz) and ${ }^{13} \mathrm{C}$ NMR (100 MHz) spectra of $N$-(4-Bromobenzyl)- $N, N, N$ triethylammonium bromide in $\mathrm{CDCl}_{3}$ 